\title{
PELAKSANAAN DIVERSI DALAM MENYELESAIKAN TINDAK PIDANA ANAK MENURUT UNDANG UNDANG NOMOR 11 TAHUN 2012 DI PENGADILAN NEGERI KUDUS (Studi Kasus di Pengadilan Negeri Kudus)
}

\author{
Muhammad Munif, Hidayatullah dan Sulistyowati \\ Email : munifmuhammad242@gmail.com, hidayatullah@umk.ac.id, \\ sulistyowati@umk.ac.id \\ Fakultas Hukum Universitas Muria Kudus
}

\begin{abstract}
ABSTRAK
Anak merupakan amanah atau titipan dari Allah SWT, sehingga anak sebagai manusia mempunyai harkat dan martabat. Harkat dan martabat tersebut patut dijunjung tinggi, selain itu anak juga mempunyai hak. Namun anak yang berhadapan dengan hukum harus tetap diproses sesuai hukum yang berlaku, yang mana proses hukumnya berbeda dengan orang dewasa. Anak yang melakukan tindak pidana diatur dalam Undang Undang Nomor 11 Tahun 2012 tentang Sistem Peradilan Pidana Anak. Berdasarkan Pasal 7 angka 2 UU SPPA tindak pidana anak yang dapat diselesaikan dengan diversi dan bukan tindak pidana pengulangan. Penelitian ini menggunakan metode pendekatan yuridis empiris. Spesifikasi penelitian ini yaitu deskriptif analitis. Teknik penentuan sampel dalam penelitian ini yaitu purposive sampling. Metode pengumpulan data dengan cara wawancara dan studi kepustakaan dengan teknik analisis kualitatif. Hasil penelitian ini dapat diketahui bahwa pada prinsipnya pelaksanaan diversi dapat dilakukan pada tingkat pemeriksaan, penyidikan, penuntutan, pemeriksaan di persidangan dan pelaksanaan putusan hakim. Diversi merupakan wewenang penegak hukum selama memenuhi persyaratan sebagaimana diatur dalam UU SPPA dan PERMA Nomor 4 Tahun 2014 tentang Pedoman Pelaksanaan Diversi dalam Sistem Peradilan Pidana Anak, yaitu ancaman hukumannya di bawah 7 tahun dan bukan tindak pidana pengulangan. Mahkamah Agung juga menanggapi permasalahan anak berhadapan dengan hukum, yaitu dengan mengeluarkan PERMA Nomor 4 Tahun 2014 tentang Pedoman Pelaksanaan Diversi dalam Sistem Peradilan Pidana Anak. Implementasi dari ide diversi tersebut dalam penanganan masalah anak yang berhadapan dengan hukum dilakukan dengan menerapkan peradilan restoratif.
\end{abstract}

Kata Kunci : Diversi, Tindak Pidana Anak, PN Kudus 


\section{PENDAHULUAN}

Anak sebagai manusia juga mempunyai harkat dan martabat. Harkat dan martabat tersebut patut dijunjung tinggi, selain itu anak juga mempunyai hak. Berdasarkan ketentuan Konvensi Hak Anak (Convention on the Rights of the Child), Pemerintah mengeluarkan Keputusan Presiden Nomor 36 Tahun 1990 tentang Konvensi Hak-Hak Anak, yang selanjutnya dituangkan di dalam Undang-Undang Nomor 4 Tahun 1979 tentang Kesejahteraan Anak dan Undang-Undang Nomor 23 Tahun 2002 tentang Perlindungan Anak (selanjutnya ditulis Undang-Undang Perlindungan Anak), peraturan perundang-undangan sebagaimana tersebut di atas semuanya mengatur prinsip-prinsip umum perlindungan terhadap anak, seperti non diskriminasi, kepentingan terbaik bagi anak, kelangsungan hidup dan tumbuh kembang anak, dan menghargai partisipasi anak.

Namun, pada kenyataannya Undang-Undang Perlindungan Anak belum dapat berjalan secara efektif, khususnya perlindungan terhadap anak yang berhadapan dengan hukum belum berjalan dengan efektif. UndangUndang Perlindungan Anak yang saat ini sudah berlaku kurang lebih 12 (dua belas) tahun akhirnya diubah dengan Undang-Undang Nomor 35 Tahun 2014 tentang Perubahan Atas UndangUndang Nomor 23 Tahun 2002 tentang Perlindungan Anak. Undang-Undang Perlindungan Anak sebagaimana tersebut di atas mengedepankan prinsip-prinsip umum perlindungan terhadap anak, yaitu non diskriminasi, kepentingan terbaik bagi Anak, kelangsungan hidup dan tumbuh kembang, dan menghargai partisipasi anak.

Masa anak-anak merupakan masa yang sangat rawan dalam proses pertumbuhan jiwa Anak, karena pada masa Anak-Anak inilah seringkali memiliki keinginan untuk melakukan sesuatu hal yang baru. Lingkungan tempat tinggal Anak sangat besar pengaruhnya terhadap pertumbuhan Anak. Anak dalam masa pertumbuhan, sangat rentan terhadap pengaruh lingkungan dan pergaulan. Seorang anak seringkali terpengaruh oleh lingkungan tempat ia bergaul dan bersosialisasi. Lingkungan yang baik akan membuat Anak menjadi baik, begitu juga sebaliknya.

Banyak anak yang harus berhadapan dengan hukum, dalam masa penahanan dititipkan di Lembaga Pemasyarakatan Orang Dewasa, seharusnya anak yang berhadapan dengan hukum, apabila proses hukumnya berjalan, maka guna untuk kepentingan penuntutan oleh Jaksa Penuntut Umum Khusus Anak, maka Anak harus dititipkan di Lembaga Penempatan Anak Sementara (LPAS), tetapi LPAS tidak terdapat di setiap Kabupaten dan Kotamadya, LPAS adanya di Kota Magelang, maka penahanan terhadap Anak yang berhadapan dengan hukum dititipkan di Lembaga Pemasyarakatan Orang Dewasa, namun penempatannya terpisah dengan tahanan Orang Dewasa.

Berdasarkan latar belakang di atas ada suatu permasalahan yang akan dibahas dalam penulisan dan penelitian ini yaitu bagaimana penerapan diversi dalam penyelesaian perkara pidana yang dilakukan oleh anak ditinjau dari 
keadilan restoratif (restorative justice)

? dan bagaimana gagasan perkembangan hukumnya tentang keadilan restoratif pada tindak pidana anak?

\section{METODE PENELITIAN}

Penelitian ini menggunakan metode pendekatan yuridis empiris, yaitu meneliti objek penelitian dengan cara terjun langsung ke lapangan, sehingga didapatkan data primer, dan didukung dengan data sekunder untuk menjawab suatu permasalahan yang ada. Data primer didapatkan melalui wawancara sedangkan data sekunder didapatkan dari bahan-bahan pustaka yang telah ada sebelumnya.

Penelitian ini menggunakan spesifikasi penelitian deskriptif analitis, yaitu menggambarkan atau mendeskripsikan dan menguraikan hasil penelitian yang berupa data primer yang diolah dan dianalisis sesuai dengan perangkat peraturan perundang-undangan yang berlaku mengenai sistem peradilan pidana anak.

\section{HASIL PENELITIAN DAN PEMBAHASAN}

\section{Penerapan Diversi dalam Penyelesaian Perkara Pidana yang Dilakukan oleh Anak Ditinjau dari Keadilan Restoratif}

Pengertian diversi menurut United Nation Standard Minimum Rules for the Administration of Juvenile Justice (The Beijing Rules), adalah kewenangan yang diberikan kepada aparat penegak hukum dalam mengambil tindakan-tindakan atau kebijaksanaan dalam menangani atau menyelesaikan pelanggaran atau tindak pidana yang dilakukan oleh anak dengan tidak mengambil jalan formal antara lain menghentikan atau tidak meneruskan/melepaskan dari proses peradilan pidana atau menyerahkan kepada masyarakat dan bentuk-bentuk kegiatan pelayanan sosial lainnya. ${ }^{16}$

Dalam diversi aparat penegak hukum menempuh penyelesaian kasus tindak pidana anak dengan cara musyawarah. Diversi menurut Pasal 1 ayat (7) UU SPPA adalah pengalihan penyelesaian perkara anak dari proses peradilan pidana ke proses di luar peradilan pidana. Tidak semua kasus pidana yang dilakukan oleh anak dapat diselesaikan secara diversi, sebagaimana diatur dalam Pasal 7 ayat (2) UU SPPA, yang menyatakan bahwa "Diversi sebagaimana dimaksud pada ayat (1) dilaksanakan dalam hal tindak pidana yang dilakukan:

a. Diancam dengan pidana penjara di bawah 7 (tujuh) tahun; dan

b. Bukan merupakan pengulangan tindak pidana.

Berdasarkan Pasal 7 ayat (2) UU SPPA, maka dapat d itarik kesimpulan bahwa penyelesaian tindak pidana yang dilakukan oleh anak dapat diselesaikan dengan cara diversi dengan syarat ancaman hukumannya dibawah 7 (tujuh) tahun, jika tindak mpidana yang dilakukan oleh anak diamcam hukumam di atas 7 (tujuh) tahun, maka tidak dapat diselesaikan dengan cara diversi. Tujuan dari pelaksanaan diversi sebagaimana diatur Pasal 6 SPPA, yang menyatakan bahwa diversi bertujuan :

a. Mencapai perdamaian antara korban dan anak;

b. Menyelesaikan perkara anak di luar proses peradilan;

\footnotetext{
${ }^{16}$ Setya Wahyudi, "Implementasi Ide Diversi", Genta Publishing, Yogyakarta, 2011, hlm. 56
} 
c. Menghindarkan anak dari perampasan kemerdekaan;

d. Mendorong masyarakat untuk berpartisipasi; dan

e. Menanamkan rasa tanggung jawab kepada anak.

Tujuan atau manfaat program diversi bagi Anak yang berhadapan dengan hukum menurut Setya Wahyudi adalah sebagai berikut: ${ }^{17}$

1) Membantu anak-anak belajar dari kesalahannya melalui intervensi selekas mungkin.

2) Memperbaiki luka-luka karena kejadian tersebut, kepada keluarga, korban dan masyarakat.

3) Kerjasama dengan pihak orang tua, pengasuh dan diberi nasehat hidup sehari-hari.

4) Melengkapi dan membangkitkan anak-anak untuk membuat keputusan untuk bertanggung jawab.

5) Berusaha untuk mengumpulkan dana untuk restitusi kepada korban.

6) Memberikan tanggung jawab anak atas perbutannya, dan memberikan pelajaran tentang kesempatan untuk mengamati akibat-akibat dan efek kasus tersebut.

7) Mengurangi beban pada peradilan dan lembaga penjara.

8) Pengandalian anak/remaja

Penyelesaian kasus anak yang berhadapan dengan hukum secara Diversi merupakan cara yang mengedepankan keadilan restoratif atau restorative justice, Dalam memberikan perlindungan terhadap anak yang berhadapan dengan hukum, selain dengan diversi penyelesaiannya juga dapat dilakukan dengan

${ }^{17}$ Ibid, hlm. 60 mengedepankan keadilan restoratif. Menurut Pasal 1 ayat (6) UU SPPA keadilan restoratif adalah penyelesaian perkara tindak pidana dengan melibatkan pelaku, korban, keluarga pelaku/korban, dan pihak lain yang terkait untuk bersama-sama mencari penyelesaian yang adil dengan menekankan pemulihan kembali pada keadaan semula, dan bukan pembalasan.

Eva Achjani Zulfa memberikan penjelasan bahwa keadilan restoratif adalah sebuah konsep pemikiran yang merespon pengembangan sistem peradilan pidana dengan menitikberatkan pada kebutuhan pelibatan masyarakat dan korban yang dirasa tersisih dengan mekanisme yang bekerja pada sistem peradilan pidana yang ada pada saat ini. ${ }^{18}$ Oleh karena itu perlu adanya solusi atau jalan keluar dalam menyelesaikan tindak pidana yang dilakukan oleh anak. Konsep diversi dan Restorative Justice merupakan jalan keluar terbaik bagi anak yang berhadapan dengan hukum. ${ }^{19}$

Al. Wisnubroto dan G. Widiartana menyhatakan bahwa keadilan restoratif dicirikan dengan beberapa preposisi, sebagai berikut $:^{20}$

a. Kejahatan adalah konflik antar individu yang mengakibatkan kerugian pada korban, masyarakat dan pelaku itu sendiri.

b. Tujuan yang harus dicapai dari proses peradilan pidana adalah

18 Eva Achjani Zulfa, Keadilan Restoratif, Badan Penerbit Fakultas Hukum Universitas Indonesia, Jakarta, 2009, hlm. 65.

${ }^{19}$ Sumartono, wawancara pribadi, Kepala Bapas Pati, tanggal 25 Januari 2018.

${ }^{20}$ Al. Wisnubroto dan G. Widiartana, Pembaharuan Hukum Acara Pidana, Citra Aditya Bakti, Bandung, 2005, hlm. 42 
melakukan rekonsiliasi diantara pihak-pihak sambil memperbaiki kerugian yang ditimbulkan oleh kejahatan.

c. Proses peradilan pidana harus dapat memfasilitasi partisipasi aktif para korban, pelanggar dan masyarakat. Tidak semestinya peradilan pidana didominasi oleh negara dengan mengesampingkan yang lainnya.

Penyelesaian tindak pidana anak dengan cara diversi dan Keadilan restoratif, jelas bertentangan dengan asas legalitas dan asa kepastian hukum (rechtzakerheid). Sebab, keadilan restoratif hasil akhirnya bukan pemidanaan atau hukuman penjara, tetapi keadilan restoratif fokus pada perbaikan dan pemulihan keadaan korban pasca terjadinya suatu tindak pidana. Sebagai ganti dari sanksi hukumnya, pelaku tindak pidana dapat menganti dengan membayar ganti rugi, kerja sosial, atau tindakan-tindakan yang masih dalam batas kewajaran yang diperintahkan oleh penegak hukum atau pengadilan.

Dalam UU SPPA diversi dimaksudkan untuk menghindari efek negatif dari pemeriksaan konvensional peradilan pidana terhadap anak yang dilakukan oleh aparat penegak hukum, dalam hal ini baik efek negatif dalam proses peradilan maupun efek negatif dalam stigma atau cap jahat, karena pernah di proses peradilan, oleh sebab itu, pemeriksaan konvensional dialihkan. Diversi dapat dilakukan pada tingkat penyidikan di Kepolisian, Kejaksaan, Pengadilan, maupun Pembina Lembaga Pemasyarakatan, dengan penyelesaian tindak pidana anak dengan diversi di semua tingkatan sebagaimana tersebut di atas, maka diharapkan dapat mengurangi efek negatif keterlibatan anak dalam proses peradilan tersebut.

Menurut Penyidik PPA Polres Kudus Suwondo tujuan utama dari pelaksanaan diversi yaitu sebagai berikut $:^{21}$

a. Untuk menghindari anak dari penahanan;

b. Untuk menghindari cap/label anak sebagai penjahat;

c. Untuk mencegah pengulangan tindak pidana yang dilakukan oleh anak;

d. Agar anak bertanggung jawab atas perbuatannya;

e. Untuk melakukan intervensiintervensi yang diperlukan bagi korban dan anak tanpa harus melalui proses formal

f. Menghindari anak mengikuti proses sistem peradilan;

g. Menjauhkan anak dari pengaruh dan implikasi negatif dari proses peradilan.

Pelaksanaan diversi pada prinsipnya dapat dilakukan di setiap tingkatan, yaitu pada tingkat pemeriksaan, penyidikan, penuntutan, pemeriksaan dipersidangan dan pelaksanaan putusan hakim. Suwondo salah satu penyidik PPA Polres Kudus memberikan penjelasan bahwa diversi dilaksanakan dengan prinnsip-prinsip seperti dibawah ini $:^{22}$

a. Anak tidak boleh dipaksa untuk mengakui tindakan pidananya;

Anak yang berhadapan dengan hukum tidak boleh dipaksa untuk mengakui perbuatannya, upaya paksa terhadap anak untuk mengakui perbuatannya dapat menimbulkan rasa

\footnotetext{
21 Suwondo, wawancara pribadi, Penyidik PPA Polres Kudus, tanggal 8 Mei 2017.

22 Suwondo, wawancara pribadi, Penyidik PPA Polres Kudus, tanggal 8 Mei 2017.
} 
tanak pada Polisi sebagai penyidik dan dapat membuat anak menjadi trauma. Dengan pendekatan secara pribadi pada anak, diharapkan anak mengakui sendiri perbuatannya, dan memberikan penjelasan kepada anak yang berhadapan dengan hukum bahwa perbuatan yang dilakukannya merupakan perbbuatan yang dilarang oleh undang-undang dan ada sanksi pidananya, dan atas perbuatannya tersebut dapat mengakibatkan kerugian terhadap orang lain.

b. Hanya dapat dilakukan bila anak mengakui kesalahan;

Dengan pendekatan yang baik dan memberikan penjelasan kepada anak yang berhadapan dengan hukum diharapkan anak mengakui sendiri perbuatannya tanpa ada paksaan dan anak tersebut mengakui kesalahannya.

\section{Gagasan perkembangan pengaturan diversi dalam konsep KUHP dan undang undang peradilan anak}

Pemerintah merespon dengan baik terhadap kasus Anak Berhadapan dengan hukum dengan mengeluarkan Undang-Undang Sistem Peradilan Pidana Anak dengan sangat progresif. Mahkamah Agung juga menanggapi permasalahan Anak Berhadapan dengan hukum, yaitu dengan mengeluarkan Peraturan Mahkamah Agung (PERMA) Nomor 4 Tahun 2014 tentang Pedoman Pelaksanaan Diversi dalam Sistem Peradilan Pidana Anak.

Implementasi dari ide diversi tersebut dalam penanganan masalah anak yang berhadapan dengan hukum dilakukan dengan menerapkan peradilan restroatif (Restorative Justice) dalam peradilan pidana anak. Sistem Peradilan Pidana Anak (Juvenile Justice System) adalah segala unsur sistem peradilan pidana yang terkait di dalam penanganan kasus kasus kenakalan anak. Pertama, polisi sebagai institusi formal ketika anak nakal pertama kali bersentuhan dengan sistem peradilan, yang juga akan menentukan apakah anak akan dibebaskan atau diproses lebih lanjut. Kedua, jaksa dan lembaga pembebasan bersyarat yang juga akan menentukan apakah anak akan dibebaskan atau diproses ke pengadilan anak. Ketiga, Pengadilan Anak, tahapan ketika anak akan ditempatkan dalam pilihanpilihan, mulai dari dibebaskan sampai dimasukkan dalam institusi penghukuman.

\section{Kesimpulan}

Berdasarkan hasil penelitian dan pembahasan, maka dapat ditarik kesimpulan sebagai berikut :

1. Penerapan Diversi dalam Penyelesaian Perkara Pidana yang Dilakukan oleh Anak Ditinjau dari Keadilan Restoratif

Pada prinsipnya pelaksanaan diversi dapat dilakukan pada setiap tingkatan, yaitu pada tingkat pemeriksaan, penyidikan, penuntutan, pemeriksaan di persidangan dan pelaksanaan putusan hakim. Diversi harus dilakukan sesuai dengan prinnsip-prinsip sebagai berikut

a. Anak tidak boleh dipaksa untuk mengakui tindakan pidananya.

b. Hanya dapat dilakukan bila anak mengakui kesalahan.

c. Pemenjaraan/penahanan bukan bagian dari diversi (tidak boleh ada pencabutan kemerdekaan anak). 
d. Adanya kemungkinan penyerahan kembali ke pengadilan bila sosial tidak berhasil.

e. Hak anak tetap diperhatikan dalam hal kasus anak diajukan ke pengadilan.

f. Tidak ada diskriminasi.

2. Gagasan perkembangan pengaturan diversi dalam konsep KUHP dan undang undang peradilan anak

Pemerintah merespon dengan baik terhadap kasus Anak Berhadapan dengan hukum dengan mengeluarkan Undang-Undang Sistem Peradilan Pidana Anak dengan sangat progresif. Mahkamah Agung juga menanggapi permasalahan Anak Berhadapan dengan hukum, yaitu dengan mengeluarkan Peraturan Mahkamah Agung (PERMA) Nomor 4 Tahun 2014 tentang Pedoman Pelaksanaan Diversi dalam Sistem Peradilan Pidana Anak.

Implementasi dari ide diversi tersebut dalam penanganan masalah anak yang berhadapan dengan hukum dilakukan dengan menerapkan peradilan restroatif (Restorative Justice) dalam peradilan pidana anak. Sistem Peradilan Pidana Anak (Juvenile Justice System) adalah segala unsur sistem peradilan pidana yang terkait di dalam penanganan kasus kasus kenakalan anak. Pertama, polisi sebagai institusi formal ketika anak nakal pertama kali bersentuhan dengan sistem peradilan, yang juga akan menentukan apakah anak akan dibebaskan atau diproses lebih lanjut. Kedua, jaksa dan lembaga pembebasan bersyarat yang juga akan menentukan apakah anak akan dibebaskan atau diproses ke pengadilan anak. Ketiga, Pengadilan Anak, tahapan ketika anak akan ditempatkan dalam pilihanpilihan, mulai dari dibebaskan sampai dimasukkan dalam institusi penghukuman.

\section{Saran}

Berdasarkan kesimpulan di atas, maka penulis memberi saran sebagai berikut :

1. Kepada Aparat Penegak Hukum, Kepolisian, Kejaksaan dan Lembaga Peradilan dapat memberikan penyuluhan atau sosialisasi kepada masyarakat tentang ide diversi sehingga masyarakat akan pentingnya diversi dalam penyelenggaraan sistem peradilan pidana anak. Mengenalkan hukum dan mengajarkan anak untuk taat hukum sejak dini juga perlu dilakukan oleh orang tua dan pendidik di sekolah.

2. Perlu dilakukan segera pembaruan sistem peradilan pidana materiil anak, sistem hukum formal anak, dan sistem pelaksanaan sanksi hukum pidana anak.

\section{DAFTAR PUSTAKA}

Al. Wisnubroto dan G. Widiartana, 2005, Pembaharuan Hukum Acara Pidana, Citra Aditya Bakti, Bandung

A.Z Abidin dan Andi Hamzah, Pengantar dalam Hukum Pidana Indonesia, Penerbit Yarsif Watampone, Jakarta, 2010

Barda Nawawi Arief, 2001, Masalah Penegakan Hukum dan Kebijakan Penanggulangan Kejahatan, Bandung, Citra Aditya Bakti.

Chairul Huda, 2011, Dari 'Tiada Pidana Tanpa Kesalahan' menuju kepada 'Tiada 
Pertanggung Jawaban Pidana Tanpa Kesalahan', Kencana, Jakarta.

Eva Achjani Zulfa, Keadilan Restoratif, 2009, Badan Penerbit Fakultas Hukum Universitas Indonesia, Jakarta.

Herlina Apong, 2004, Perlindungan terhadap Anak yang Berhadapan dengan Hukum, Buku Saku Untuk Polisi, Unicef, Jakarta.

M. Nasir Djamil, 2013, Anak Bukan Untuk Dihukum, Sinar Grafika, Jakarta.

Marlina, 2010, Pengantar Konsep Diversi dan Restorative Justice dalam Hukum Pidana, Medan, USU Press.

Mardjono Reksodiputro, 1993, Sistem Peradilan Pidana Indonesia (Melihat Kepada Kejahatan Dan Penegakan Hukum Dalam Batas - Batas Toleransi), Fakultas Hukum Unversitas Indonesia.

Muladi dan Barda Nawawi Arief, 2005, Teori-Teori dan Kebijakan Pidana.

Muladi, 1995, Kapita Selekta Sistem Peradilan Pidana, Badan Penerbit Universitas Diponegoro, Semarang.

Setya Wahyudi, 2011, Implementasi Ide Diversi Dalam Pembaharuan Sistem Peradilan Pidana Anak di Indonesia, Genta Publising Yogyakarta.

\section{Perundang-Undangan :}

UUD NRI Tahun 1945

Kitab Undang Undang Hukum Pidana Kitab Undang Undang Hukum Acara Pidana
Undang Undang Nomor 11 Tahun 2012

Tentang Sistem Peradilan Pidana Anak;

Undang Undang Nomor 35 Tahun 2014 Tentang Perubahan Atas Undang Undang Nomor 23 Tahun 2002 Tentang Perlindungan Anak

Putusan PN Kudus Nomor : 1/Pen.Diversi/2016/PN.Kds.

Putusan PN Mungkid Nomor : 7/Pen.Div/2014/PN.Mkd 